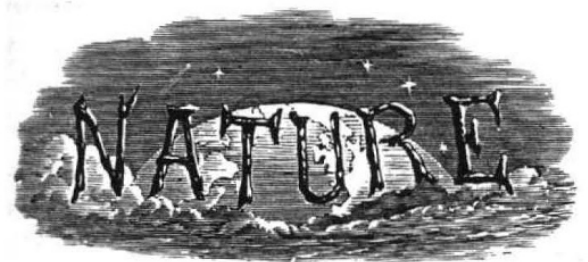

SATURDAY, JANUARY 20, I934

No. 3351

CONTENTS

Industrial Research

Numbers and Numerology. By Dr. Thomas Greenwood

Physiological Balance in the Body

Tables of the Planets ${ }_{\text {Meterological Science and Art. By G. T. W. }}$

Short Reviews

The John Murray Expedition to the Arabian Sea. By Lieut.-Col. R. B. Seymour Sewell, C.I.E.

Recent Discoveries at Choukoutien. By Prof. Davidson Black, F.R.S.

Obituary :

Prof. J. Joly, F.R.S. By Prof. Henry H. Dixon, F.R.S. and Dr. J. H. J. Poole

Mr. H. F. Biggs

News and Views

Letters to the Editor :

A Suggested Explanation of $\beta$-Ray Activity.-Prof. M. N. Saha, F.R.S. and D. S. Kothari .

Activities of Life and the Second Law of Thermodynamics.-Prof. F. G. Donnan, C.B.E., F.R.S.

Artificial Production of the Blue Fluorescence of Fluorite.-H. Haberlandt, Berta Karlik and

Prof. K. Przibram
Interpretation of the Benedicks Effect.-Dr.

Lothar Nordheim * C C
Chemistry of Cheddar Cheese-making.-Dr. F. H. McDowall and Dr. R. M. Dolby -
Condensation of Water in the Atmosphere.Col. E. Gold, O.B.E., F.R.S.

Measurements of Submarine Daylight.- - Hans Pettersson and Svante Landberg .

Structure of Collagen Fibres and the Point of Attack by Proteolytic Enzymes.-Dr. D. Jordan Lloyd and M. E. Robertson . Lord Cottesloe, C.B. .

Leonids Observations from an Aeroplane.-Dr. Hubert Slouka . . . . . .

External Leaf-Characters of the Cricket-Bat and other Willows.-Dr. H. Bancroft

The Term 'Mesolithic'.-Harold J. E. Peake

Influence of Pressure on the Spontaneous Inflammation of Hydrocarbons.-M. Neumann and V. Estrovich

Raman Spectrum of Heavy Water.--Prof. R. W. Wood, For. Mem. R.S. .

Molecular Polarisations of Nitrobenzene in Various Solvents at $25^{\circ}$ C. - H. O. Jenkins .

Integral Right-angled Triangles.--F. S. Richards

Research Items

International Mathematical Congress Medals .

Narcosis and Mental Function

Constitution of the Alloys of Iron and Manganese.

By F. C. T.

University and Educational Intelligence

Science News a Century Ago

Societies and Academies

Forthcoming Events

Official Publications Received
PAGE

77

80

82

82

83

84

86

\section{Industrial Research}

PARTICULAR attention is given to the work and position of industrial research associations in the annual report of the Department of Scientific and Industrial Research issued a few days ago. The reason for this is that the fund of one million pounds granted by Parliament nearly sixteen years ago for the promotion of industrial research in Great Britain, through research associations, has now been exhausted, and the time has come for the whole subject to be surveyed, as well as for the consideration of a policy for the future. When an industry is protected by a tariff, the State should demand in return that the industry is maintained in a condition of progressive efficiency; and this can only be achieved through continued developments of methods and processes. Some large industrial concerns are in the position to maintain extensive research departments themselves; but if the existence of these establishments means that the co-operative work of the industrial research associations is left to smaller firms, and that some of the associations have to close down for lack of adequate financial support, the result, from a national point of view, will be unfortunate-to say the least.

The Department of Scientific and Industrial Research was formed during the War as the result of a memorial from the Royal Society and other scientific and technical societies to the Government in May 1915 urging that assistance should be afforded "for scientific research for industrial purposes". In response to this appeal, a Committee of Council, presided over by the Lord President of Council, was constituted, with an Advisory Council of scientific men and industrialists. The functions of this Council were : (1) To act as scientific advisers to all Government departments concerned with, or interested in, scientific research. (2) With the co-operation of scientific societies, to consider the application of science to industry and enlist the interest of manufacturers. (3) To advise the Board of Education as to steps which should be taken to increase the supply of workers competent to undertake scientific research.

In the year 1917 Parliament placed a sum of one million pounds sterling at the disposal of the Committee of Council for the promotion of industrial research; and a scheme was drawn up for the establishment of research associations connected with various industries, each of which 
was to receive for five years a grant on a fiftyfifty basis in aid of its expenses. From the first, the guiding principle of the Department of Scientific and Industrial Research has been to induce the industries to do things for themselves rather than to attempt to do scientific work for them. In the fifteen years during which the million pound fund was available, five thousand or so firms contributed $£ 1,750,000$ to the support of their industrial research associations, and there are nineteen such associations now in existence. At present Parliament provides $£ 65,000$ a year and industry $£ 170,000$ towards the support of these associations. Most of the associations have established their own research laboratories, but others have their investigations carried out at the National Physical Laboratory and in universities and similar institutions.

The industrial research associations represent, however, only one side of the activities of the Department, which has also established a number of special stations on a large scale for building research, chemical research, food investigation, forest products research, fuel research, radio research, and water pollution research. During the past year, seventy-six per cent of the expenditure of the Department has been used for these stations and thirteen per cent in support of industrial research associations.

Although the Department has done a great deal to encourage fundamental scientific research in universities and other institutions, and is in close co-operation with the Royal Society, which receives an annual grant from the State in aid of purely scientific investigations, quite properly there has been no attempt to organise such research. Such a proceeding would be repugnant to the best research workers. At the same time no expenditure has ever earned such big dividends for industry and for the community as the money spent on pure research. One has only to think of such things as the modern electric lamp, the wireless valve and the photoelectric cell--products of pure research on atomic physics-to realise this. Although the majority of new knowledge which springs from fundamental research undoubtedly finds its application in industry, nevertheless the lag between scientific discovery and its use in industry has in the past been far too long.

Leaders of industry are finding that the methods followed by the men of science in approaching their problems can be followed with advantage in tackling many of the problems confronting modern industry. The result of this during the last few years has been the organisation of research sections in many of the larger industrial concerns, and the formation of the industrial research associations to serve the interest of industries where the units of production are similar.

One of the best illustrations of the way that science is strengthening the chains of production is that of one of our oldest industries, the wool trade. In the first place, wool is not a standardised raw material ; many factors such as soil, climate, disease, gland secretions, food and management affect the quality of the wool. The influence of all these factors on fibre qualities such as strength, diameter, elasticity and so on, which play an important part in manufacture, are being scientifically investigated. Methods of controlling them are being sought with the view of reducing variations in the quality of the raw material. In the second place, the older methods of processing the wool, have, in the case of nearly all our older industries, been worked out without conscious planning. The methods of science are therefore being applied in the technical improvement of these processes, and ways are being sought through the application of science for cutting costs and increasing efficiency.

The first of these two aspects of wool research concerns the big wool-growing countries, Australia and South Africa, and the work on these aspects is being carried out in Australia, for example, under the Commonwealth Department of Scientific and Industrial Research. The link, however, between that work and inquiries seeking to discover how wool qualities are affected by feeding and by the soil, is the Wool Industries Research Association. The Association has suggested that elasticity is directly connected with the sulphur content of the wool fibre. It has been found that sheep obtain sulphur in the form of a protein called 'cystine', and accordingly experiments are in progress overseas on the effect of extra cystine with the object of raising the sulphur content of the wool. Similarly fineness in the wool may be due to deficiency in phosphorus.

The same kind of link between the Empire grower and the manufacturer is maintained by the Shirley Institute, which is the Research Laboratory of the British Cotton Industry Research Association, where there is a staff of more than 200 , of whom about 70 are fully qualified scientific investigators. The income of the Association is well over $£ 50,000$ a year, four-fifths of which is 
subscribed by the trade and the remainder by the Department of Scientific and Industrial Research. Eighty per cent of the cotton firms in the country engaged in all parts of the industry from spinning to finishing are members of the Association. The work of the Association has resulted in producing a large number of small improvements which sitogether reach a substantial total. It has been cajculated that a saving of something like $£ 300,000$ a year is being effected in Lancashire by the research carried out by the Research Association. This gives a return of about 500 per cent on the money invested in research.

One of the most productive researches ever carried out under the auspices of the Department depended mainly on the measurement of the conductivity of heat of soils and insulating materials. Cables distributing electric power in populated areas are, of course, put underground. The electric currents naturally heat them, and the amount of current they can carry depends on the rate at which this heat is conducted away. Accurate measurements on this point, carried out on behalf of the Electrical and Allied Industries Research Association, indicated that the heat conducted away was in most cases greater than had been supposed. It was therefore shown that existing cables could be further loaded with safety to an extent representing a capital value in cables of $£ 4,000,000$.

Related to this subject are investigations into the deterioration of lead sheath cables arranged by the Non-Ferrous Metals Research Association and carried out at the Research Department, Woolwich. Lead sheath cables, though generally excellent in service, were found to suffer failures on board ship, in submarine and aerial cables where movements by tide or wind could occur, in railway service of bridges, in tunnels and, in fact, in all positions where they suffer exceptional vibration. The breakdowns were very troublesome as the failure started from the inner part of the sheath and could not be seen until a complete breakdown of the sheath took place. The cause was investigated by the Research Association, which was able to produce two new ternary alloys of lead containing lead-cadmium-antimony and leadcadmium-tin which have a fatigue resistance three and a half times as great as the ordinary pure lead. These alloys have solved the problem with regard to the deterioration of lead cable sheathing. It may be remarked that 80,000 tons per annum are used in Great Britain for this purpose and in the United States one company alone uses 75,000 tons of lead for the sheathing of telephone cables. The new alloy is used on the new Post Office submarine telephone cable to France. In addition to this better fatigue resistance, the new alloy is also at least fifty per cent stronger than pure lead in other respects, and it is therefore likely that it will have a great future for improved water pipes.

These examples selected from recent reports illustrate the bearing of scientific research upon industrial progress and commercial profits. It would be easy to advance many others to show that scientific research should be looked upon not as a last resource but as an essential part in the business of production. It is now generally recognised that the initial advantages which Great Britain secured through her island position, her natural resources, and the technical skill of her workers, are no longer sufficient in themselves to enable our manufacturers to withstand the organised and scientific rivalry of competing countries. The full utilisation of the results of scientific research, and the substitution of scientific for empirical methods can, however, only be secured as a result of confidence in the scientific workers engaged in the study of the problems concerned and of acquaintance with the existence and value of this large body of scientific knowledge and research.

Although scientific methods are much more widely used in almost all our industries than even a few years ago, there is not yet a general disposition to accept an adequate and sustained programme of research as a fixed charge, comparable with insurance, depreciation, obsolescence, etc., without which no industry can progress, if indeed it can survive. Science, whether in its broadest aspect or its narrow technical sense, will not occupy its proper place in industry until the industrialist is prepared not merely to admit its possibilities and accept its occasional assistance but also to incorporate it as part of his industrial practice. Such incorporation involves not merely the support of research work, whether conducted in his own laboratories or outside, or in co-operation with other firms, but also continuous contact with research in matters of interest to his industry, wherever that research is prosecuted.

With such convincing records as those mentioned in the report of the Department, of the financial advantage and public benefit derived from scientific research, particularly in the province of electrical engineering, it would seem to be unnecessary to urge that electrical manufacturers 
and supply companies might reasonably be expected to devote a fraction of one per cent of their profits to research, whether in university laboratories or by co-operative effort. Leaving purely scientific investigations out of consideration, there are many technical problems awaiting solution, and great savings and economies may be confidently anticipated from systematic research into them, yet the funds provided to the British Electrical and Allied Industries Research Association for such work are a very poor return for benefits received or belief in favours to come. The annual revenue of the electric supply authorities in Great Britain is about $£ 45,000,000$, and so far their annual contribution to the funds of the Association has only reached about $£ 5,000$, though they are benefiting by research done or nearing completion to the extent of a sum approaching $£ 1,000,000$ per annum. If the public attention given to the recent report of the Department of Scientific and Industrial Research should lead to a wider understanding and more generous recognition of both scientific and industrial research from manufacturers and corporations who profit by the results, it will have achieved a most useful national purpose.

\section{Numbers and Numerology}

Numerology. By Prof. E. T. Bell. Pp. vii +187. (Baltimore, Md.: The Williams and Wilkins Co.; London: Baillière, Tindall and Cox, 1933.) $11 s .6 d$.

" $\mathrm{C}$ VERYThing is Number!" Thus spake the son of Mnesarchus. Ever since these
words were uttered, not only have philosophers vied with each other to find a correct interpretation of them, but also the world has turned its back to the fact-finding approach to human affairs and still enjoys the rhetorical approach of numerology. Pythagoras was thus the founder of esoterism and arithmosophy as well as of science and philosophy. If the number of followers of any particular doctrine are to be taken as a criterion of its value, then esoterism and arithmosophy may well be given the palm.

The predominance of number in the world of appearance is obvious. Ancient religions and ancient philosophies recognise a quantitative order in the universe, whatever be their conceptions about its origin. The rhythm of life, the rhythm of Nature and the rhythm of the heavens have always appealed to the imagination of man.
Number and proportion, its subtler aspect, dominate the practical arts of man. Without number, there would be no commerce, no architecture, no medicine, no religious cults, and none of the crafts appearing between these landmarks of human interests. This profound truth must have been revealed to Pythagoras by the sages of the East with whom he came into contact, and was probed by his own observations and meditations. For example, his exaltation in submitting the imponderable vibrations of sound to the law of number, inspired him with his famous doctrine of the harmony of the spheres, when he dogmatically imposed certain numerical proportions between the celestial bodies and their movements. It is this Pythagorean spirit which Plato inherited, as is shown in the "Timæus", where he builds up the universe by means of numerical proportions and geometrical figures, a process which culminates in the construction of the five regular solids. Moreover, we believe it is not far from the truth to assume that Euclid himself had a Pythagorean vision before him when he wrote his everlasting "Elements". It is significant to observe that his thirteen books end with the construction of the regular solids, as if their author were not interested in the other types of curves and solids already known in his time, once he had given to the world the rational steps leading to the understanding of the wonderful figures with which Plato had created the soul and the universe.

This spirit, dormant during the Middle Ages, which were more interested in ethical numerology, becomes supreme again during the Renaissance. The mathematisation of astronomy by Copernicus and Kepler, and the foundation of modern mechanics by Galileo on the firm ground of number, were in the best Pythagorean tradition. So also was the establishment of analytical geometry by Descartes, a new science which may be considered as a refined form of the arithmetical geometry of Pythagoras. Again, the invention of the calculus by Newton and Leibniz gave the man of science new tools for combining his mathematical picture of the universe. Ever since, not only have astronomy, physics and chemistry come more and more under the influence of the law of number, but also biology, psychology and sociology. Indeed, the most comprehensive thought ever conceived by man is short: the cosmos is isomorphic with pure mathematics; an obvious generalisation of the old Pythagorean saying that everything is number. At present, 